\title{
Predictors of virological treatment failure among adult HIV patients on first-line antiretroviral therapy in Woldia and Dessie hospitals, Northeast Ethiopia: a case-control study
}

Mohammed Ahmed ${ }^{1 *}$, Hailu Merga ${ }^{2}$ and Habtemu Jarso ${ }^{2}$

\begin{abstract}
Background: Virological treatment failure is a problem that a Human Immune Virus patient faces after starting treatment due to different factors. However, there were few studies done on the predictors of virological treatment failure among adult patients on first-line antiretroviral therapy in Ethiopia in general, and no study was done in the study area in particular. Therefore, the aim of the study was to identify predictors of virological treatment failure among adult patients on first-line antiretroviral therapy in Woldiya and Dessie Hospitals, Northeast Ethiopia.

Method: Hospital based case-control study was conducted in Woldia and Dessie Hospitals from from 12 August 2016-28 February 2018 on 154 cases and 154 controls among adult patients on first-line antiretroviral treatment. All cases were included and comparable controls were selected using stratified random sampling technique. Data were collected by document review using checklists and entered into Epidata version 3.1 and analyzed by SPSS version 21. Multivariable logistic regression analysis was done to identify the independent predictors of virological treatment failure.

Results: In this study, statistically higher odds of virological failure was observed among patients who had current CD4 T-cell count of $<200 \mathrm{~mm}^{3}$ (AOR $\left.=2.4,95 \% \mathrm{Cl}: 1.35,4,18\right)$ compared withCD4 T-cell count of $>200 \mathrm{~mm}^{3}$, current body mass index $(\mathrm{BMI})<16 \mathrm{~kg} / \mathrm{m}^{2}(\mathrm{AOR}=4.2,95 \% \mathrm{Cl}: 1.85,9.51)$ compared with $\mathrm{BMI}>18.5 \mathrm{~kg} / \mathrm{m}^{2}$, BMl between 16 and $18.5 \mathrm{~kg} / \mathrm{m}^{2}(\mathrm{AOR}=3.72,95 \% \mathrm{Cl}: 1.75,7.92)$ versus $\mathrm{BMI}>18.5 \mathrm{~kg} / \mathrm{m}^{2}$, poor adherence to antiretroviral therapy ( $A O R=5.4,95 \% \mathrm{Cl}: 2.95,9.97)$ compared with good adherence.

Conclusion: This study showed that low current CD4 T-cell count and body mass index, as well as poor adherence for ART treatment predicts virological failure. Therefore, deliberate efforts are urgently needed in HIV care through improving their nutritional status by enhancing nutritional education and support, and by strengthening enhanced adherence counseling.
\end{abstract}

Keywords: Virological treatment failure, First-line, Antiretroviral treatment, Case control study, Woldia, Dessie Ethiopia

\footnotetext{
* Correspondence: mohaasrar12@gmail.com

${ }^{1}$ Department of Public Health, Woldia University, Woldia, Ethiopia

Full list of author information is available at the end of the article
}

(c) The Author(s). 2019 Open Access This article is distributed under the terms of the Creative Commons Attribution 4.0 International License (http://creativecommons.org/licenses/by/4.0/), which permits unrestricted use, distribution, and reproduction in any medium, provided you give appropriate credit to the original author(s) and the source, provide a link to the Creative Commons license, and indicate if changes were made. The Creative Commons Public Domain Dedication waiver (http://creativecommons.org/publicdomain/zero/1.0/) applies to the data made available in this article, unless otherwise stated. 


\section{Background}

The global scale-up of antiretroviral treatment (ART) under the public health approach of standardized and simplified regimens has registered significant gains, with increasing access to treatment for millions of people, and a reduction in new infections and Human Immune Virus(HIV)-associated morbidity and mortality [1]. Globally, $82 \%$ of people on treatment had suppressed viral loads.Similarly, in Eastern and Southern Africa at the end of $201683 \%$ were virally suppressed, contributing to $29 \%$ reduction in new HIV infections between 2010 and 2016 [2].

The primary goal of ART is to prevent HIV-associated morbidity and mortality and an effective ART can reduce viremia and transmission of HIV to sexual partners by more than 96\% [3]. Therefore, Monitoring people on ART is important to ensure successful treatment, identify adherence problems and determine whether ART regimens should be switched in case of treatment failure, which can be assessed in three ways: clinically, immunologically, and virologically; whichprovides an early and more accurate indication of treatment failure [4].

The World Health Organization (WHO) and Ethiopian National guideline defines virological treatment failure as plasma viral load above 1000 copies/ml (based on two consecutive viral load measurements after 3 months with enhanced adherence support) after at least 6 month of ART treatment [4-6]. Different studies showed that virological failure is a problem that an HIV patient faces after starting treatment and the magnitude of the problem is apparent in different countries:20.8\% in China [7], 16\% in Swaziland [8], 24.6\% in Kenya [9], 24\% in Mozambique [10], 41.3\% in Gabon [11], 11.9\% in Rwanda [12], 11\% in Uganda [13], and 10.7\% in Bahirdar, Ethiopia [14].

At the individual patient level, failed ART regimen or HIV drug resistance limits treatment options, complicates succession of therapy and puts the patient at increased risk for drug toxicity $[15,16]$ which in turn has both human and financial consequences [6]. Mathematical modeling predicts that if levels of non-nucleoside reverse transcriptase inhibitors (NNRTI) drug resistance exceed $10 \%$ in sub-Saharan Africa, between 2016 and 2020 drug resistance is predicted to be responsible for an additional 105,000 new HIV infections, 135,000 AIDS deaths, and US\$ 650 million in Antiretroviral drug costs [6]. Several studies showed that various factors were positively associated with virological treatment failure such as poor adherence to treatment $[9,10,12,13,17,18]$, low baseline CD4 count $[8,10,17,19,20]$, younger age $[9,10,12,17]$, longer time on ART [17, 21], being male in gender [21], advanced WHO staging $[10,20]$, and lower current CD4 count [17]. On the other hand, disclosed HIV status of patients, and extra baseline weight was negatively associated with virological failure [19, 22]. However, in Ethiopia, there were few studies done on the predictors of virological treatment failure among adult patients on first-line antiretroviral therapyusing routine viral load testing as a measure of treatment failure in in general, and no study was done in the study area in particular. Identifying and intervening determinants of virological treatment failure is important to achieve high treatment success rate. The aim of this study was therefore to assess the predictors of virological treatment failure among adult patients on first-line antiretroviral therapy at Woldiya and Dessie Hospitals, Northeast Ethiopia.

\section{Methods}

\section{Study design and setting}

Facility based unmatched case control study conducted in Woldia General and Dessie Referral Hospitals, North East Ethiopia from 12 August 2016-28 February 2018 with data extraction period from March 13-27/2018. Both Hospitals started ART services in 2005 and serving for HIV infected patients until now. Routine viral load test was started after 12 August 2016 in both hospitals. According to the information from the records of the hospitals, between 12 August 2016 to 28 February 2018, there were 9013 adult patients on first -line ART that had two consecutive documented viral load tests result in Woldiya and Dessie hospitals. From 9013 adult patients that had two consecutive documented viral load test result in both hospitals, 154 (51 in Woldia and 103 in Dessie hospital) and 534 (236 in Woldiya and 298 in Dessie hospital) of them had viral load result of above 1000 and $\leq 1000$ copies $/ \mathrm{ml}$, respectively. All HIV-infected patients aged 15 years and above who had taken first-line ART for at least 6 months with two consecutive documented viral load test results were the source population. All cases and selected controls who had documented viral load test results from 12 August 2016-28 February 2018 were the study population. HIV-infected patients aged 15 years and above whose plasma viral load was $>1000$ copies/ $\mathrm{ml}$ in 2 consecutive viral load measurements in a 3-month interval with enhanced adherence support after at least 6 months of starting first-line ART regimen is defined as cases (virological treatment failure) whereas HIV-infected patients aged 15 years and above whose plasma viral load was $<1000$ copies $/ \mathrm{mL}$ in 2 consecutive viral load measurements after at least 6 months of starting first-line ART regimen is defined as controls (without virological failure).

\section{Sample size estimation and sampling technique}

Sample size was determined using Epi Info7 version 3.5.3, by taking age less than 35 years as predictor of 
virological treatment failure which gave larger sample size [17], 1:1 case to control ratio, 95\% Confidence interval (CI), power of $80 \%$, and it becomes 288 (144 cases and 144 controls). However, to improve the power of the study, all of the cases (154) and comparable controls (154) were included in the study. Stratified random sampling technique was employed to select controls as study participants. First, sampling frame was prepared based on patient MRN from recorded documents of each hospital for controls separately. Then, the total sample sizes of the controls were allocated for each hospital proportionally to the number of controls. Finally, systematic random selection was applied for the selection of allocated controls (68 from Woldiya hospital and 86 from Dessie hospital) based on respective sampling interval.

\section{Data collection instrument and quality control}

Data were extracted by document review using a structured checklist prepared in English adapted from Ethiopian Federal Ministry of Health ART clinic intake and follow up form. Data collectors and supervisors were trained for two days about the objectives of the study, contents of tools and how to collect the data before the data collection. The data was collected by 6 ART trained nurses that work at ART clinic. Two runners were used for bringing cards from the card room. The principal investigator and the supervisors were closely monitored the whole data collection process on a daily basis. To keep the quality of the study, document review checklist was prepared based on federal ministry of health of Ethiopia standard ART intake and follow up form. Data collectors and supervisors were ART trained nurse. Training was given for data collectors and supervisors before data collection and there was close follow up of data collectors by supervisors and the principal investigator including observation of how they were extracting the recorded data. Moreover, data quality was also ensured during collection, entry.

\section{Data processing and analysis}

Data were checked for completeness, coded and, finally it was entered into Epi Data version 3.1, cleaned and analyzed by using SPSS version 21. Descriptive statistics, including frequencies mean and percentages were used to describe demographic, clinical, and treatment-related characteristics of patients. Binary logistic regression analysis was carried out for independent variables with an outcome variable to select candidate variables for multivariable analysis.

Table 1 Baseline socio-demographic characteristics of HIV infected patients on First-line antiretroviral treatment at Woldia and Dessie hospitals, 2018

\begin{tabular}{|c|c|c|c|c|}
\hline Variables & Category & Cases: N (\%) & Controls: N (\%) & $p$-value for Chi-square test \\
\hline \multirow[t]{2}{*}{ Age (years) } & $\leq 35$ & $119(77.3)$ & $111(72.1)$ & 0.295 \\
\hline & $>35$ & $35(22.7)$ & $43(27.9)$ & \\
\hline \multirow[t]{2}{*}{ Sex } & Male & $69(44.8)$ & $71(46.1)$ & 0.819 \\
\hline & Female & $85(55.2)$ & $83(53.9)$ & \\
\hline \multirow[t]{5}{*}{ Marital status } & Never married & $46(29.9)$ & $37(24)$ & 0.593 \\
\hline & Married & $73(47.4)$ & $81(52.6)$ & \\
\hline & Separated & $6(3.9)$ & $3(2)$ & \\
\hline & Divorced & $18(11.7)$ & $22(14.3)$ & \\
\hline & Widowed & $11(7.1)$ & $11(7.1)$ & \\
\hline \multirow[t]{4}{*}{ Educational status } & No education & $57(37)$ & $55(35.7)$ & 0.852 \\
\hline & Primary & $59(38.3)$ & $66(42.9)$ & \\
\hline & Secondary & $28(18.2)$ & $24(15.6)$ & \\
\hline & Tertiary & $10(6.5)$ & $9(5.8)$ & \\
\hline \multirow[t]{6}{*}{ Occupational status } & Farmer & $52(33.8)$ & $47(30.5)$ & 0.475 \\
\hline & House Wife & $17(11)$ & $19(12.3)$ & \\
\hline & Student & $13(8.4)$ & $11(7.1)$ & \\
\hline & Merchant & $11(7.1)$ & $9(5.8)$ & \\
\hline & Employed & $24(15.6)$ & $31(20.1)$ & \\
\hline & Unemployed & $37(24)$ & $37(24)$ & \\
\hline \multirow[t]{2}{*}{ HIV serostatus disclosure } & Yes & $107 \quad(69.5)$ & $114(74)$ & 0.376 \\
\hline & No & $47(30.5)$ & $40(26)$ & \\
\hline
\end{tabular}


Variables with a $p$-><?A3B2 twb.?>value $<0.25$ in bivariate analysis were included into a multivariable logistic regression analysis using backward likelihood ratio method to identify the independent predictors of virological treatment failure. The final model was assessed for goodness-of-fit using Hosmer-Lemeshow test. No evidence indicating lack of fit was found $(p$-value $=0.298)$. Finally, variables that had significant associations with virological treatment failure were identified based on the adjusted odd ratio (AOR) with a $95 \% \mathrm{CI}$ and $p$-value $<0.05$. And also, effect modifications among independent predictors were assessed using interaction term and no effect modification was found.

\section{Results}

Socio-demographic characteristics of respondents

A total number of participants included in the study were 308 (154 cases and 154 controls). At baseline, the mean age of the cases and controls were 30 years (SD: 8 years) and 31 years (SD: 9 years) respectively. About $55.2 \%$ of cases and $53.9 \%$ of the controls were females; likewise, $47.4 \%$ of cases and $52.6 \%$ of the controls were married. Similarly, $38.3 \%$ of cases and $42.9 \%$ of the controls were attained primary education. By their occupation, $33.8 \%$ of cases and $30.5 \%$ of the controls were farmers. About 69.5 and $74 \%$ of the cases and controls, respectively were, disclosed their serostatus (Table 1 ).

Table 2 Clinical related characteristics of HIV infected patients treated at Woldia and Dessie hospitals, 2018

\begin{tabular}{|c|c|c|c|c|}
\hline \multirow[t]{2}{*}{ Variables } & \multirow[t]{2}{*}{ Category } & \multirow{2}{*}{$\begin{array}{l}\text { Cases }(n=154) \\
\text { Frequency (\%) }\end{array}$} & \multirow{2}{*}{$\begin{array}{l}\text { Controls }(n=154) \\
\text { Frequency (\%) }\end{array}$} & \multirow{2}{*}{$\begin{array}{l}\text { p-value for } \\
\text { Chi-square tes }\end{array}$} \\
\hline & & & & \\
\hline \multirow{3}{*}{$\begin{array}{l}\text { Baseline body mass } \\
\text { index (BMI) }\end{array}$} & $<16$ & $14(9.1)$ & $16(10.4)$ & \multirow[t]{3}{*}{0.349} \\
\hline & $16-18.5$ & 44 (28.6) & $33(21.4)$ & \\
\hline & $>18.5$ & $96(62.3)$ & $105(68.2)$ & \\
\hline \multirow[t]{3}{*}{ Current BMI } & $<16$ & $27(17.5)$ & $10(6.5)$ & \multirow[t]{3}{*}{$<0.001$} \\
\hline & $16-18.5$ & $37(24)$ & $12(7.8)$ & \\
\hline & $>18.5$ & $90(58.4)$ & $132(85.7)$ & \\
\hline \multirow[t]{2}{*}{ Baseline CD4 T-cell count } & $\leq 200$ & $98(63.6)$ & $91(59.1)$ & \multirow[t]{2}{*}{0.413} \\
\hline & $>200$ & $56(36.4)$ & $63(40.9)$ & \\
\hline \multirow[t]{2}{*}{ Current CD4 T-cell count } & $\leq 200$ & $62(40.3)$ & $30(19.5)$ & \multirow[t]{2}{*}{$<0.001$} \\
\hline & $>200$ & $92(59.7)$ & $124(80.5)$ & \\
\hline \multirow[t]{2}{*}{ Base line $\mathrm{Hgb}(\mathrm{g} / \mathrm{dl})$} & $\leq 12$ & $51(33.1)$ & $43(27.9)$ & \multirow[t]{2}{*}{0.322} \\
\hline & $>12$ & $103(66.9)$ & $111(72.1)$ & \\
\hline \multirow[t]{3}{*}{ Functional status } & Working & $85(55.2)$ & $89(57.8)$ & \multirow[t]{3}{*}{0.295} \\
\hline & Ambulatory & $64(41.6)$ & $55(35.7)$ & \\
\hline & Bedridden & $5(3.2)$ & $10(6.5)$ & \\
\hline \multirow[t]{4}{*}{ WHO staging at baseline } & stage 1 & $17(11)$ & $27(17.5)$ & \multirow[t]{4}{*}{0.347} \\
\hline & stage 2 & $57(37)$ & $50(32.5)$ & \\
\hline & stage 3 & $66(42.9)$ & $60(39)$ & \\
\hline & stage 4 & $14(9.1)$ & $17(11)$ & \\
\hline \multirow[t]{3}{*}{ Treatment staging ${ }^{a}$} & T1 stage & $140(90.9)$ & $135(87.7)$ & \multirow[t]{3}{*}{0.643} \\
\hline & T2 stage & $10(6.5)$ & $13(8.4)$ & \\
\hline & T3 stage & $4(2.6)$ & $6(3.9)$ & \\
\hline \multirow[t]{3}{*}{ HIV duration ${ }^{b}$} & $<24$ months & $7(4.5)$ & $7(4.5)$ & \multirow[t]{3}{*}{0.985} \\
\hline & 24-48 months & 19 (12.3) & $20(13)$ & \\
\hline & $>48$ months & $128(83)$ & $127(82.5)$ & \\
\hline \multirow[t]{2}{*}{ TB before starting ART } & Yes & $28(18.2)$ & $34(22)$ & \multirow[t]{2}{*}{0.394} \\
\hline & No & $126(81.8)$ & $120(78)$ & \\
\hline \multirow[t]{2}{*}{ TB after starting ART } & Yes & $3(2)$ & $2(1.3)$ & \multirow[t]{2}{*}{0.652} \\
\hline & No & $151(98)$ & $152(98.7)$ & \\
\hline
\end{tabular}

${ }^{\mathrm{a} C l i n i c a l ~ s t a g e ~ o f ~ H I V ~ p a t i e n t s ~ a f t e r ~ s t a r t i n g ~ a n t i r e t r o v i r a l ~ t r e a t m e n t ~}$

${ }^{b}$ the time includes both before and after starting ART following first HIV positive test 
Table 3 Treatment related characteristics of HIV infected patients treated at Woldia and Dessie hospitals, 2018

\begin{tabular}{|c|c|c|c|c|}
\hline \multirow[t]{2}{*}{ Variables } & \multirow[t]{2}{*}{ Category } & \multirow{2}{*}{$\begin{array}{l}\text { Cases(n=154) } \\
\text { Frequency (\%) }\end{array}$} & \multirow{2}{*}{$\begin{array}{l}\text { Controls ( } \mathrm{n}=154) \\
\text { Frequency (\%) }\end{array}$} & \multirow{2}{*}{$\begin{array}{l}\text { p-value for } \\
\text { Chi-square test }\end{array}$} \\
\hline & & & & \\
\hline \multirow[t]{3}{*}{ Duration on ART } & $<24$ months & $8(5.2)$ & $9(5.8)$ & \multirow[t]{3}{*}{0.781} \\
\hline & 24-48 months & $22(14.3)$ & $26(16.9)$ & \\
\hline & $>48$ months & $124(80.5)$ & $119(77.3)$ & \\
\hline \multirow[t]{2}{*}{ Adherence level to ART treatment } & Good & $89(57.8)$ & $135(87.7)$ & \multirow[t]{2}{*}{$<0.001$} \\
\hline & Poor & $65(42.2)$ & 19 (12.3) & \\
\hline \multirow[t]{2}{*}{ History of CPT } & Yes & $139(90.3)$ & $127(82.5)$ & \multirow[t]{2}{*}{0.046} \\
\hline & No & $15(9.7)$ & $27(17.5)$ & \\
\hline \multirow[t]{2}{*}{ History of IPT } & Yes & $8(5.2)$ & $16(10.4)$ & \multirow[t]{2}{*}{0.089} \\
\hline & No & $146(94.8)$ & $138(89.6)$ & \\
\hline \multirow[t]{5}{*}{ Regimen at the start of ART } & $\mathrm{d} 4 \mathrm{t}+3 \mathrm{TC}+\mathrm{NVP}$ & $32(20.8)$ & $26(16.9)$ & \multirow[t]{5}{*}{0.931} \\
\hline & $\mathrm{AZT}+3 \mathrm{TC}+\mathrm{NVP}$ & $46(29.9)$ & $50(32.5)$ & \\
\hline & $\mathrm{AZT}+3 \mathrm{TC}+\mathrm{EFV}$ & $30(19.5)$ & $30(19.5)$ & \\
\hline & TDF+3TC+EFV & $37(24)$ & $38(24.7)$ & \\
\hline & $\mathrm{TDF}+3 \mathrm{TC}+\mathrm{NVP}$ & $9(5.8)$ & $10(6.5)$ & \\
\hline \multirow[t]{4}{*}{ First line regimen currently } & $\mathrm{AZT}+3 \mathrm{TC}+\mathrm{NVP}$ & $53(34.4)$ & $58(37.7)$ & \multirow[t]{4}{*}{0.733} \\
\hline & $\mathrm{AZT}+3 \mathrm{TC}+\mathrm{EFV}$ & $32(20.8)$ & $31(20)$ & \\
\hline & $\mathrm{TDF}+3 \mathrm{TC}+\mathrm{EFV}$ & $48(31.2)$ & $50(32.5)$ & \\
\hline & $\mathrm{TDF}+3 \mathrm{TC}+\mathrm{NVP}$ & $21(13.6)$ & $15(9.8)$ & \\
\hline \multirow[t]{2}{*}{ Change of ART regimen or individual drug } & Yes & $45(29.2)$ & $47(30.7)$ & \multirow[t]{2}{*}{0.803} \\
\hline & No & $109(70.8)$ & $107(69.5)$ & \\
\hline \multirow[t]{2}{*}{ History of treatment interruption } & Yes & $6(3.9)$ & $4(2.6)$ & \multirow[t]{2}{*}{0.520} \\
\hline & No & $148(96.1)$ & $150(97.4)$ & \\
\hline
\end{tabular}

\section{Clinical related characteristics of respondents}

Among the participants, $62.3 \%$ of cases and $68.2 \%$ of controls were classified as BMI > 18.5 at baseline; $59.7 \%$ of cases and $80.5 \%$ of controls had current CD4 count of $>200$. Moreover, $42.9 \%$ of cases and $39 \%$ of the controls were classified as Stage III at baseline. About $83 \%$ of cases and $82.5 \%$ of controls had HIV duration $>48$ months. In this study, $18.2 \%$ of cases and $22 \%$ of the controls had history of TB before starting ART, while $2 \%$ of cases and $1.3 \%$ of the controls had history of TB after starting ART (see Table 2 below).

\section{Treatment related characteristics of respondents}

This study revealed that $80.5 \%$ of cases and $77.3 \%$ of the controls were on ART for $>48$ months. About $42.2 \%$ of cases and $12.3 \%$ of the controls had history of poor adherence for ART treatment. Moreover, $90.3 \%$ of cases and $82.5 \%$ of the controls had history of Cotrimoxazole prophylaxis therapy; $5.2 \%$ of cases and $10.4 \%$ of the controls had history of Isonized prophylaxis therapy. At the start of ART $29.9 \%$ of cases and $37 \%$ of the controls were on 1c regimen $(\mathrm{AZT}+3 \mathrm{TC}+\mathrm{NVP})$. The study showed $29.2 \%$ of cases and $11.7 \%$ of the controls had history of regimen change/individual drug (see Table 3 below).

\section{Predictors of virological treatment failure}

In bivariate logistic regression analysis, factors such as Marital status, WHO staging, baseline BMI, Current BMI, current CD4 T-cell count, Adherence to ART treatment, history of Cotrimoxazole Prophylaxis therapy, history of Isonized Prophylaxis therapy were associated with virological failure at $P$-value of $<0.25$.

When variables that had association with virological failure in the bivariate analysis $(P$-value $<0.25)$ were all included in multivariable logistic regression model using backward likelihood ratio method (LR) it was found that current BMI, adherence level to ART treatment, and Current CD4T-cell count had statistically significant association with virological failure ( $p$-value $<0.05)$.

In this study, the odds of virological failure was 2.4 times more $(\mathrm{AOR}=2.4,95 \%$ CI: $1.35,4.18)$ among those who had Current CD4 T-cell count of $\leq 200$ $\mathrm{mm}^{3}$ compared with those who had Current CD4 
Table 4 Multivariable logistic regression analysis shows predictors of Virological failure among first-line ART users at Woldia and Dessie Hospitals, 2018

\begin{tabular}{|c|c|c|c|c|c|c|c|}
\hline Variables & Category & Cas & es: N (\%) & Controls: N (\%) & $\operatorname{COR}(95 \% \mathrm{Cl})$ & $\mathrm{AOR}(95 \% \mathrm{Cl})$ & $p$-value \\
\hline Current & $\leq 200$ & 62 & $(40.3)$ & $30(19.5)$ & $2.79(1.67,4.65)$ & $2.4(1.35,4.18)$ & $0.003^{*}$ \\
\hline CD4 count $\left(\mathrm{mm}^{3}\right)$ & $>200$ & 92 & $(59.7)$ & $124(80.5)$ & 1 & 1 & \\
\hline \multirow[t]{3}{*}{ Current BMI (kg/m²) } & $<16$ & 27 & $(17.5)$ & $10 \quad(6.5)$ & $3.96(1.83,8.58)$ & $4.2(1.85,9.51)$ & $0.001^{*}$ \\
\hline & $16-18.5$ & 37 & (24) & $12 \quad(7.8)$ & $4.52(2.24,9.14)$ & $3.7(1.75,7.92)$ & $0.001^{*}$ \\
\hline & $>18.5$ & 90 & (58.4) & $132 \quad(85.7)$ & 1 & 1 & \\
\hline \multirow[t]{2}{*}{ Adherence level to ART } & Good & 89 & $(57.8)$ & $135 \quad(87.7)$ & 1 & 1 & $<0.0001^{*}$ \\
\hline & Poor & 65 & $(42.2)$ & $(12.3)$ & $5.2(2.91,9.24)$ & $5.4(2.95,9.97)$ & \\
\hline
\end{tabular}

*- shows p-value $<0.05$ (statistically significant association) 1- shows reference category. Hosmer - lemeshow test ( $p$-value=0.298)

T-cell count of $>200 \mathrm{~mm}^{3}$. The odds of virological failure was 4.2 times more (AOR $=4.2,95 \% \mathrm{CI}: 1.85,9.51$ ) among those who had Current BMI of $<16 \mathrm{~kg} / \mathrm{m}^{2}$ compared with those who had Current BMI of $>18.5 \mathrm{~kg} / \mathrm{m}^{2}$. In addition, the odds of virological failure was 5.4 times more $(\mathrm{AOR}=5.43,95 \% \mathrm{CI}: 2.95,9.97)$ among those who had poor adherence compared with those who had good adherence to antiretroviral treatment (see Table 4).

\section{Discussion}

This study was aimed to assess predictors of virological failure among first-line ART users and showed that low current CD4 T-cell count count $\left(\leq 200 \mathrm{~mm}^{3}\right)$, low current BMI $\left(<16 \mathrm{~kg} / \mathrm{m}^{2}\right.$ and $\left.16-18.516 \mathrm{~kg} / \mathrm{m}^{2}\right)$, Poor adherence to ART were found to have increased odds of virological failure.

In this study, the odds of virological failure were 2.4 times more among those who had current CD4 count of $\leq 200 \mathrm{~mm}^{3}$ compared with those who had Current CD4 T-cell count of $>200 \mathrm{~mm}^{3}$. The finding is supported by studies conducted in Northwestern Uganda [22], Gonder, Ethiopia [17]. It is well known that CD4 T-cell counthas an inverse relationship with viral replication and load. As patients' immune status becomes declined, the rate of viral replication increases compared to their immune-competent counterparts. In addition, clients with compromised immunity are more vulnerable to different opportunistic infections that sustain the vicious cycle of immunity and viral replication [3].

The odds of virological failure were 4.2 times more among those who had Current BMI of $<16 \mathrm{~kg} / \mathrm{m}^{2}$ compared with those who had Current BMI of $>18.5$ $\mathrm{kg} / \mathrm{m}^{2}$. Likewise, the odds of virological failure were 3.7 times more among those who had Current BMI between 16 and $18.5 \mathrm{~kg} / \mathrm{m}^{2}$ compared with those who had Current BMI of $>18.5 \mathrm{~kg} / \mathrm{m}^{2}$. This finding is supported by a study conducted Northwestern Uganda [22]. It is evident that low BMI is correlated significantly with the decrease in CD4 count and the increase in viral load by progressing in to the advanced stage of the disease, and by exposing the patients not taking ART medication (poor adherence) [23, 24].

In addition, the odds of virological failure were 5.4 times more among those who had poor adherence compared with those who had good adherence to antiretroviral treatment. This finding is supported by studies conducted in Uganda [13], Zimbabwe [20], Rwanda [12], Kenya [9], and Gonder, in Ethiopia [17]. It is grossly apparent that poor adherence to medication reduce treatment response due to suboptimal drug concentration and by doubling the viral load or viral replication, which leads to virological failure [25, 26]. This confirms that achieving long-term good adherence is indeed Achilles' heel of successful virologic outcomes. The limitation of this study were being record based methods of data collection, which restrict the number of variables that would be studied such as psycho social factors (Depression, stigma) and differences in quality of care and service in each hospital.

\section{Conclusion}

The present study revealed that, the key predictors for virological failure were low current (recent) CD4 count, low current (recent) body mass index, and poor adherence to antiretroviral treatment. Therefore, deliberate efforts are urgently needed in HIV care by concerned bodies like ART case managers, adherence counselors in the hospitals on patients with low body mass index, low current CD4 count (through improving their nutritional status by enhancing nutritional education and support), and improving poor adherence to ART treatment by strengthening enhanced adherence counseling.

\section{Abbreviations}

AIDS: Acquired Immune Deficiency Syndrome; AOR: Adjusted Odd Ratio; ART: Antiretroviral Treatment; BMI: Body Mass Index; CD4: Cluster Designated 4; Cl: Confidence Interval; CPT: Cotrimoxazole Prophylaxis Therapy; HIV: Human Immune Virus; IPT: Isonized Prophylaxis Therapy; NNRTI: Non Nucleoside Reverse Transcriptase Inhibitors; PLHIV: Patient Living With Human Immune Virus; RNA: Ribonucleic Acid; UNAIDS: United Nation Programme on Acquired Immune Deficiency Syndrome; WHO: World Health Organization 


\section{Acknowledgments}

We would like to thank Woldiya and Dessie Hospitals administrative bodies for the provision of the needed data for our study and we also thank to data collectors and supervisors.

\section{Funding}

The study was fully funded by Jimma University, Institute of health.

\section{Availability of data and materials}

The datasets used or analyzed during the current study are available from the corresponding author on reasonable request.

\section{Author's contributions}

MA: conceived the research idea, conducted the data collection, data analysis and data interpretation, wrote and reviewed the paper. $\mathrm{HJ}$ and $\mathrm{HM}$, supervises the data collection and analysis, reviewed and approved the final manuscript. All authors' read and approved the final manuscript.

\section{Ethics approval and consent to participate}

Ethical clearance was obtained from the Institutional Review Board of institute of health, Jimma University. Permission was also obtained from Woldia and Dessie Hospitals administrative bodies prior to document review.

\section{Consent for publication}

Not applicable.

\section{Competing interests}

The authors declare that they have no competing interests.

\section{Publisher's Note}

Springer Nature remains neutral with regard to jurisdictional claims in published maps and institutional affiliations.

\section{Author details}

'Department of Public Health, Woldia University, Woldia, Ethiopia. 2Department of Epidemiology, Institute of health, Jimma University, Jimma, Ethiopia.

Received: 7 January 2019 Accepted: 20 March 2019

Published online: 03 April 2019

\section{References}

1. WHO. HIV drug resistance report 2017. In: Geneva; 2017.

2. UNAIDS. Ending AIDS Progress towards the 90-90-90 targets. 2017;

3. AIDSinfo. Guidelines for the Use of Antiretroviral Agents in HIV-1-Infected Adults and Adolescents. 2016.

4. WHO. Consolidated Guidelines on the use of Antiretroviral Drugs for treating and preventing HIV Infection Recommendations for a Public Health Approach. 2nd edi. Geneva; 2016.

5. FDREMOH. National Guidelines for comprehensive HIV prevention. In: Care and treatment; 2014

6. WHO. Tackling HIV Drug Resistance : Trends, Guidelines And Global Action. 2017:1-4

7. Leng X, Liang S, Ma Y, Dong Y, Kan W, Goan D, et al. HIV virological failure and drug resistance among injecting drug users receiving fi rst-line ART in China. BMJ open. 2014:1-8

8. Jobanputra K, Parker LA, Azih C, Okello V, Maphalala G, Kershberger B, et al. Factors Associated with Virological Failure and Suppression after Enhanced Adherence Counselling, in Children, Adolescents and Adults on Antiretroviral Therapy for HIV in Swaziland. 2015;450:1-12.

9. Hassan AS, Nabwera HM, Mwaringa SM, Obonyo CA, Sanders EJ, De WTFR, et al. HIV-1 virologic failure and acquired drug resistance among first-line antiretroviral experienced adults at a rural HIV clinic in coastal Kenya : a cross-sectional study. AIDS research and therapy. 2014;11(1):9.

10. Pou C, Maculuve S, Ceden S, Luis L, Rodrı J, Clotet B, et al. Determinants of virological failure and antiretroviral drug resistance in Mozambique. J Antimicrobial Chemother. 2017:2639-47.

11. Vella C, Eymard-duvernay S, Sica J, Makosso L, Mongo AD, Boue V, et al. Short report Virological failure rates and HIV-1 drug resistance patterns in patients on first-line antiretroviral treatment in semirural and rural Gabon. J Int AIDS Soc. 2012;(VI):17985.
12. Ndahimana A, Riedel DJ, Mwumvaneza M, Sebuhoro D, Uwimbabazi JC, Kubwimana $\mathrm{M}$, et al. Drug resistance mutations after the first 12 months on antiretroviral therapy and determinants of virological failure in Rwanda. Tropical Med Int Health. 2016;21(7):928-35.

13. Bulage L, Ssewanyana I, Nankabirwa V, Nsubuga F, Kihembo C, Pande G, et al. Factors associated with Virological non- suppression among HIV-positive patients on antiretroviral therapy in Uganda, august 2014 - July 2015. BMC. 2017:1-11.

14. Brhane BG, Nibret E, Abay GK. HIV/AIDS treatment failure and its determinant factors among first line HAART patients at Felege-Hiwot referral hospital, Bahir Dar, northwest. AIDS Clin Res. 2017;8(11).

15. Gebreab B, Barnabas G, Sibhatu MK, Berhane Y. Antiretroviral Therapy Program in Ethiopia Benefits From Virology Treatment Monitoring. Ethiopian J Health Sci. 2017:10-1.

16. Ayalew MB, Kumilachew D, Belay A, Getu S, Teju D, Endale D, Tsegaye Y, Wale Z. First-line antiretroviral treatment failure and associated factors in HIV patients at the University of Gondar Teaching Hospital, Gondar, Northwest Ethiopia. HIV/AIDS (Auckland, NZ). 2016;8:141-6.

17. Bayu B, Tariku A, Bulti AB, Habitu YA, Derso T, Teshome DF. Determinants of virological failure among patients on highly active antiretroviral therapy in University of Gondar Referral Hospital, Northwest Ethiopia. HIV/AIDS (Auckland, NZ). 2017:153-9.

18. Bezabhe WM, Chalmers L, Bereznicki LR, Peterson GM. Adherence to Antiretroviral Therapy and Virologic Failure. Medicine. 2016:95(15):1-9.

19. Ramadhani HO, Thielman NM, Landman KZ, Ndosi EM, Gao F, Kirchherr JL, et al. Predictors of Incomplete Adherence, Virologic Failure, and Antiviral Drug Resistance among HIV-Infected Adults Receiving Antiretroviral Therapy in Tanzania. Clin Infect Dis. 2017:45:1492-8.

20. Bangure $D$, Mungati $M$, Chemhuru M. Factors associated with human immunodeficiency virus first line treatment failure in Zvishavane District. Austin J HIV. AIDS Res. 2015:2(1):1-6.

21. Davey DJ, Abrahams Z. Factors associated with unsuppressed viral load in HIV-1 infected patients on 1 st line antiretroviral therapy in South Africa. Int J STD AIDS. 2017;(6):603-10.

22. Izudi J, Alioni S, Kerukadho E, Ndungutse D. Virological failure reduced with HIV- serostatus disclosure, extra baseline weight and rising CD4 cells among HIV-positive adults in northwestern Uganda. BMC Infect Dis [Internet]. 2016;1 (8) Available from: https://doi.org/10.1186/s12879-016-1952-x.

23. Duggal S, Das CT, Duggal AK. HIV and Malnutrition : Effects on Immune System. Clin Dev Immunol. 2012;2012

24. Batterham M, Brown D, Garsia R. Nutritional management of HIV/AIDS in the era of highly active antiretroviral therapy : a review. Australian J Nut Diet. 2001;1:211-23.

25. Nachega JB, Marconi VC, Zyl GU, Van GEM, Preiser W, Hong SY, et al. HIV treatment adherence, drug resistance. Virologic Failure: Evolving Concepts. 2016:11(2):167-74

26. Olowookere SA, Adewole IF. Effects of adherence to antiretroviral therapy on body mass index, immunological and virological status of Nigerians living with HIV/AIDS. Alexandria J Med [Internet]. 2016;52(1):51-4 Available from: https://doi.org/10.1016/j.ajme.2015.03.001.

Ready to submit your research? Choose BMC and benefit from:

- fast, convenient online submission

- thorough peer review by experienced researchers in your field

- rapid publication on acceptance

- support for research data, including large and complex data types

- gold Open Access which fosters wider collaboration and increased citations

- maximum visibility for your research: over $100 \mathrm{M}$ website views per year

At BMC, research is always in progress.

Learn more biomedcentral.com/submission 